\title{
Effects of aspect ratio and specimen size on uniaxial failure stress of iron green bodies at high strain rates
}

\author{
Yuki Kuroyanagi ${ }^{1, \text { a }}$, Masahiro Nishida ${ }^{1}$, Takashi Ogura ${ }^{1}$, H.-Å. Häggblad ${ }^{2}$, P. Jonsén ${ }^{2}$, and G. Gustafsson ${ }^{2}$ \\ ${ }^{1}$ Nagoya Institute of Technology, Gokiso-cho, Showa-ku, Aichi, 466-8555, Japan \\ ${ }^{2}$ Luleå University of Technology, 97187 Luleå, Sweden
}

\begin{abstract}
Powder metallurgy is used for the production of a number of mechanical parts and is an essential production method. These are great advantages such as product cost effectiveness and product uniqueness. In general, however parts created by powder metallurgy have low strength because of low density. In order to increase strength as well as density, new techniques such as high-velocity-compaction (HVC) was developed and further investigation has been conducted on improvement of techniques and optimum condition using computer simulation. In this study, the effects of aspect ratio and specimen size of iron green bodies on failure strength of uniaxial compression and failure behavior were examined using a split Hopkinson pressure Bar. The diameters of specimens were $12.5 \mathrm{~mm}$ and $25 \mathrm{~mm}$ the aspect ratios (thickness/diameter) were 0.8 and 1.2 .
\end{abstract}

\section{Introduction}

Powder metallurgy is the serial process of blending fine powder (mixture), compressive them into a desired shape (compacting), and then heating the compressed material (sintering). This is used for the production of a number of mechanical parts and is an essential production method. There are great advantages such as product cost effectiveness and product uniqueness. In general, parts created by powder metallurgy have low strength because of low density. The production of high strength parts having complex shape is required [1-4]. In order to increase strength following the increment of density, new techniques such as high velocity compaction (HVC) were developed and further investigation have been conducted on improvement of techniques and optimum condition using computer simulation [5,6]. In general, the typical material model of iron green bodies used in the simulation is modified Drucker-Prager cap model (modified DPC model) is often used. In order to estimate the modified DPC model parameter is necessary tested about uniaxial compression, shear, diametral compression, uniaxial tension test. The authors' group has been examining the strain rate sensitivity of strength and determination of material parameter of iron green bodies (iron based powder compacts) at high strain rate [7].

In this study, the effects of aspect ratio and specimen size of iron green bodies on failure strength of uniaxial compression were examined using a split Hopkinson Pressure Bar (SHPB). During dynamic compression, the failure behavior of specimens was also observed using a high speed video camera. The failure stress and failure behavior of dynamic compressive tests were compared with those of static tests.

\footnotetext{
${ }^{a}$ Corresponding author: $\mathrm{k}_{-} y u k i \_0227 @ y a h o o . c o . j p$
}

\section{Experimental methods}

\subsection{Specimens}

The powder material used for the experiments was a press-ready premix containing Distaloy AE, $0.5 \%$ graphite (uf-4) and $0.6 \%$ Kenolube. Distaloy $\mathrm{AE}$ is a pre-alloyed water atomized iron powder from Höganäs $\mathrm{AB}$, Sweden. Kenolube is a lubricant from the same supplier. The theoretical pore free density of this mix is $7.52 \mathrm{~g} / \mathrm{cm}^{3}$. The specimens were manufactured by conventional compaction (Dartec RK 250). Cylindrical specimens were manufactured with a thickness of $10 \mathrm{~mm}$ and $15 \mathrm{~mm}$, a diameter of $12.5 \mathrm{~mm}$ with $6.9 \mathrm{~g} / \mathrm{cm}^{3}$. Table 1 listed the size of specimen. Figure 1 shows a photograph of specimens. To confirm the effect of only the aspect ratio, aluminum alloy (A2024-T4) showing less strain rate dependence was used for examining the effects of aspect ratio and the diameter of specimens by SHPB.

\subsection{Experimental setup}

The dynamic compressive tests were carried out using a SHPB method. Figure 2 is shown experimental set up for dynamic compressive tests. The input and output bars for the SHPB experiments were made of steel, and their diameter and length were $32 \mathrm{~mm}$ and $2300 \mathrm{~mm} / 1700 \mathrm{~mm}$ respectively. Strain gages were put on both sides of input bar and output bar $1150 \mathrm{~mm}$ and $300 \mathrm{~mm}$ away from the specimen. The stress and strain histories of specimens were calculated from the strain of bars measured by the strain gages based on following equations [8-11].

$$
\begin{gathered}
\sigma(t)=\frac{A E}{A_{s}} \varepsilon_{t}(t) \\
\varepsilon=\frac{c_{0}}{l_{s}} \int_{0}^{t}\left[\varepsilon_{i}\left(t^{\prime}\right)-\varepsilon_{r}\left(t^{\prime}\right)-\varepsilon_{t}\left(t^{\prime}\right)\right]
\end{gathered}
$$

This is an Open Access article distributed under the terms of the Creative Commons Attribution License 4.0, which permits unrestricted use, distribution, and reproduction in any medium, provided the original work is properly cited. 
Table 1. Size of specimens.

\begin{tabular}{|c|c|c|c|}
\hline $\begin{array}{c}\text { Density } \\
{\left[\mathrm{g} / \mathrm{cm}^{3}\right]}\end{array}$ & $\begin{array}{c}\text { Diameter } \\
{[\mathrm{mm}]}\end{array}$ & Thickness $[\mathrm{mm}]$ & $\begin{array}{c}\text { Aspect } \\
\text { ratio }\end{array}$ \\
\hline \multirow{2}{*}{6.9} & 12.5 & 10 & 0.8 \\
\cline { 2 - 4 } & 25.0 & 15 & 1.2 \\
\cline { 2 - 4 } & 20 & 0.8 \\
\hline
\end{tabular}

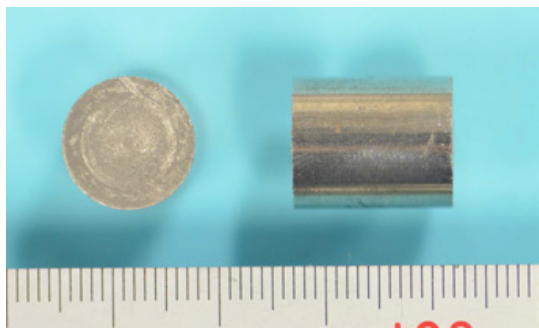

Figure 1. Photograph of specimen.

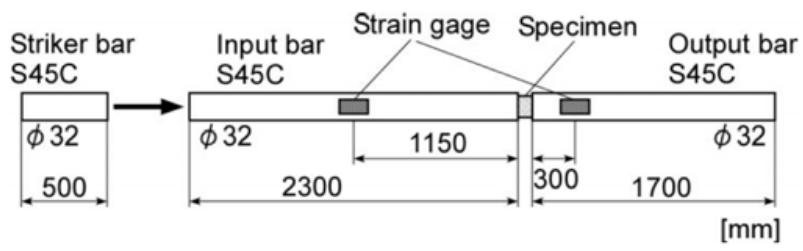

Figure 2. Experimental set up for dynamic compressive tests.

Table 2. Material constants of input and output bars.

\begin{tabular}{|l|c|c|}
\hline Density & $\begin{array}{l}\text { Elastic wave velocity of } \\
\text { the input/output bar, } c_{0}\end{array}$ & $\begin{array}{l}\text { Young's } \\
\text { modulus, } E\end{array}$ \\
\hline $7.85 \mathrm{~g} / \mathrm{cm}^{3}$ & $5110 \mathrm{~m} / \mathrm{s}$ & $208 \mathrm{GPa}$ \\
\hline
\end{tabular}

where $\varepsilon_{i}, \varepsilon_{r}$ and $\varepsilon_{t}$ are the axial strains in the input bar induced wave and reflected wave from the specimen and the axial strain in the output bar induced by the transmitted wave. $E$ and $c_{0}$ are Young's modulus and elastic wave velocity of the input and output bars, respectively. $l_{s}$ is the specimen thickness. $A$ and $A_{s}$ are the areas of cross sections of the input/output bars and the specimens. Material constants of the steel bars used in the calculation are shown in Table 2. We used steel strikers with a diameter of $32 \mathrm{~mm}$ and length of $500 \mathrm{~mm}$. During dynamic compression, we observed failure behaviour of specimens using a high speed video camera (Photron FASTCAM1024PCI 100K, frame rate of 18000 frames /sec).

\section{Result and discussion}

Figures 3-5 are shown a stress-strain curve of a dynamic compressive test. Figure 3 shows the results of aspect ratio 0.8. Figure 4 shows the results of aspect ratio 1.2. Figure 5 shows the results of specimen diameter $12.5 \mathrm{~mm}$. After the strain history and stress history of the $6.9 \mathrm{~g} / \mathrm{cm}^{3}$ specimen were calculated from the strain gages using Eqs. (1) and (2), the stress-strain curve was obtained. Figures 3-5 show first, the stress increased with strain. Second, the nominal stress-strain curve showed a peak. Finally, after the peak, the stress decreased gradually with strain. An image at strain 0.009 (56 $\mu \mathrm{s}$ after impact)

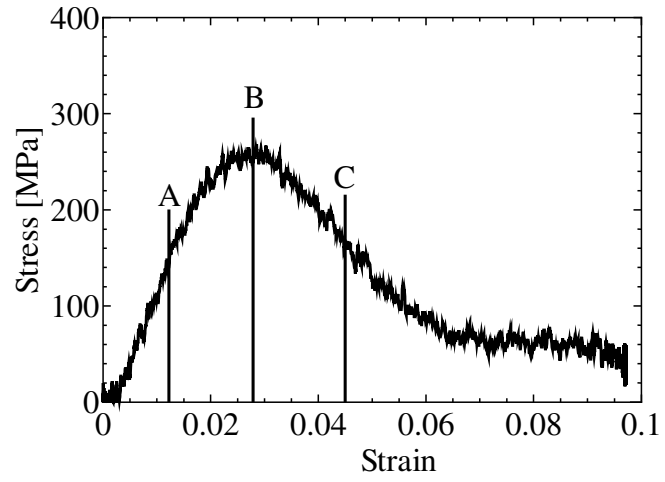

Point A Strain 0.012 $(56 \mu \mathrm{s})$

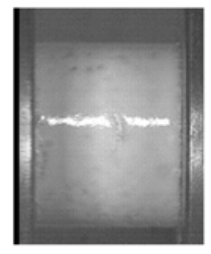

Point B, Strain $0.028 \quad$ Point C, Strain 0.045

$$
(111 \mu \mathrm{s}) \quad(166 \mu \mathrm{s})
$$
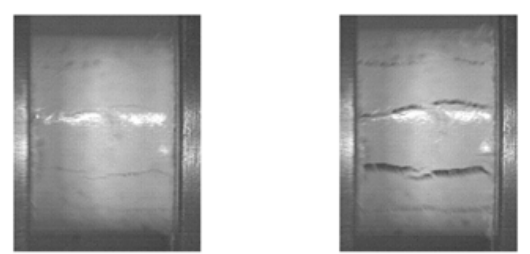

Figure 3. Stress-strain curve of dynamic compressive test and observe specimen (aspect ratio 0.8 ).

showed that any cracks on the surface of specimen were not observed. At $111 \mu \mathrm{s}$, small cracks in the compression direction on the surface of specimen started to be observed. At $166 \mu \mathrm{s}$, the cracks in the compression direction was progressed, finally specimens broke into small pieces. There was no difference of aspect ratio and the diameter of specimens in the failure behaviour. Table 4 listed the maximum stresses of iron green bodies.

It is common knowledge that aluminium alloys show small strain rate dependence. At first, the effects of aspect ratio and specimen size on yield stress were examined using aluminium alloy A2024-T4. Table 3 shows the yield stresses of the aluminum alloy A2024-T4 by SHPB. The yield stress of aspect ratio 0.8 was about 1.09 times higher than that of the aspect ratio 1.2. The yield stress of the diameter of specimen 12.5 was about 1.15 times higher than that of the diameter of specimen $25 \mathrm{~mm}$. The maximum stresses of iron green bodies were corrected using the values obtained by the ratio of yield stress in Table 3. Table 4 shows that the corrected maximum stress of aspect ratio 1.2 was larger than the maximum stress of aspect ratio 0.8 when the diameter was $12.5 \mathrm{~mm}$. The corrected maximum stress of specimen diameter $25 \mathrm{~mm}$ is larger than that of $12.5 \mathrm{~mm}$. 


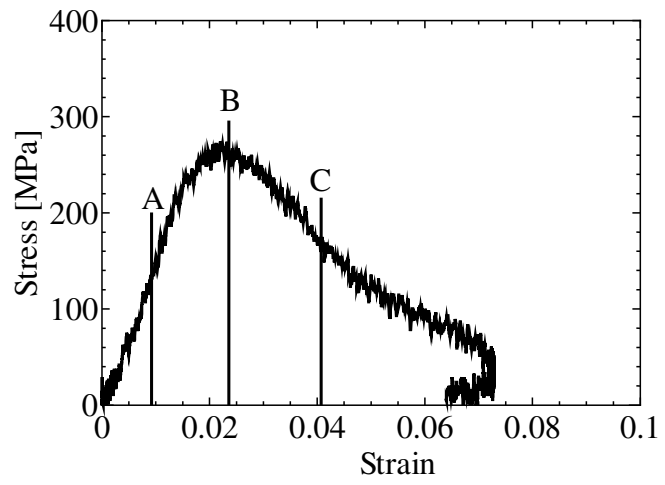

Point A, Strain 0.009 (56 $\mu \mathrm{s})$

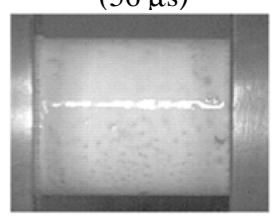

Point B, Strain 0.024 $(111 \mu \mathrm{s})$

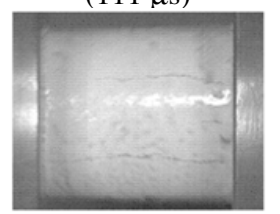

Figure 4. Stress-strain curve of dynamic compressive test and observe specimen (aspect ratio 1.2).

Table 3. Effects of aspect ratio and specimen size (Aluminum alloy A2024-T4).

\begin{tabular}{|c|c|c|c|c|c|}
\hline $\begin{array}{c}\text { Diameter } \\
{[\mathrm{mm}]}\end{array}$ & $\begin{array}{c}\text { Thickness } \\
{[\mathrm{mm}]}\end{array}$ & $\begin{array}{c}\text { Aspect } \\
\text { ratio }\end{array}$ & $\begin{array}{c}\text { Yield } \\
\text { stress } \\
{[\mathrm{MPa}]}\end{array}$ & \multicolumn{2}{|c|}{$\begin{array}{c}\text { Ratio of } \\
\text { yield stress }\end{array}$} \\
\hline \multirow{2}{*}{12.5} & 10 & 0.8 & 543 & 1.09 & 1.15 \\
\cline { 2 - 6 } & 15 & 1.2 & 500 & 1.00 & \\
\hline 25.0 & 20 & 0.8 & 473 & & 1.00 \\
\hline
\end{tabular}

Table 4. Effects of aspect ratio and specimen size (Iron green body).

\begin{tabular}{|c|c|c|c|c|}
\hline $\begin{array}{c}\text { Diameter } \\
{[\mathrm{mm}]}\end{array}$ & $\begin{array}{c}\text { Thickness } \\
{[\mathrm{mm}]}\end{array}$ & $\begin{array}{c}\text { Aspect } \\
\text { ratio }\end{array}$ & $\begin{array}{c}\text { Maximum } \\
\text { stress } \\
{[\mathrm{MPa}]}\end{array}$ & $\begin{array}{c}\text { Corrected } \\
\text { value of } \\
\text { maximum } \\
\text { stress [MPa] }\end{array}$ \\
\hline \multirow{2}{*}{12.5} & 10 & 0.8 & 267 & \\
\cline { 2 - 5 } & 15 & 1.2 & 275 & 300 \\
\hline 25.0 & 20 & 0.8 & 261 & 298 \\
\hline
\end{tabular}

\section{Conclusions}

The effects of aspect ratio and specimen size on the maximum stress and failure behaviour were examined at high strain rate. The aspect ratio and the diameter of specimens clearly affected the maximum stress. However, there is no difference in failure behaviour. It was found that the maximum stress increased with aspect ratio.

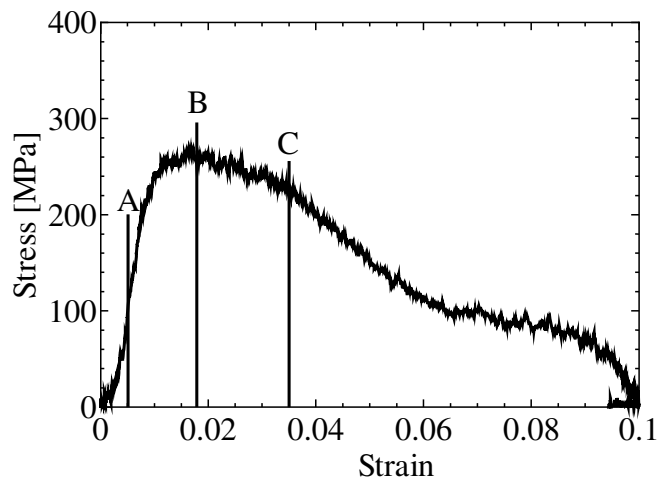

Point A, Strain 0.005

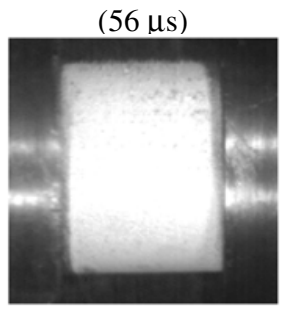

Point B, Strain 0.019

Point C, Strain 0.04 $(111 \mu \mathrm{s})$ $(166 \mu \mathrm{s})$
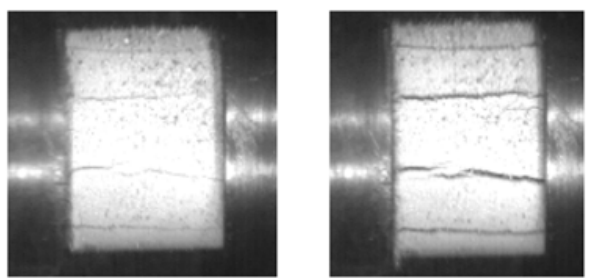

Figure 5. Stress-strain curve of dynamic compressive test and observe specimen (the diameter of specimen $25 \mathrm{~mm}$ ).

The authors are also greatly indebted to Associate Professor Fumihiro Itoigawa at Nagoya Institute of Technology for his help with taking images using a high speed camera.

\section{References}

[1] G. Gustafsson, M. Nishida, H-Å. Häggblad, H. Kato, P. Jonsén, T. Ogura, Powder Technology 268, 293 (2014)

[2] Höganäs handbook for sintered components, Höganäs AB (1997)

[3] MPIF Standard 35, Materials Standards for P/M Structural Parts (2000) edition

[4] MPIF Powder Metallurgy Design Solutions (1999)

[5] P. Jonsén, H-Å. Häggblad, L. Troive, J. Furuberg, S. Allroth and P. Skoglund, Materials Science Forum, 534-536, 289-292 (2007)

[6] M. Nishida, H. Kato, H.-Å. Häggblad, P. Jonsén, G. Gustafsson, Proc. PM2012, Yokohama (2012)

[7] G. Gustafsson, M. Nishida, H.-Å. Häggblad, H. Kato, P. Jonsén, T. Ogura, Powder Technology 239, 231238 (2013)

[8] B. Hopkinson, Philosophical transactions of the Royal Society of London 213, 437-456 (1914) 
[9] H. Kolsky, Proceedings of the Physical Society of London 62, 676-700 (1949)

[10] G.T. Gray III, Classic split-Hopkinsonbar testing, AMS Handbook, Vol.8, Mechanical Testing and
Evaluation, H. Khunand D. Medlin, eds, Material Park, Ohio, ASM International, pp. 462-476 (2000)

[11] W. Chen and B. Song, Split Hopkinson(Kolsky) bar design, testing and applications (Springer 2010) 